\title{
CD40mAb adjuvant induces a rapid antibody response that may be beneficial in post-exposure prophylaxis
}

\author{
Vijay NS Bhagawati-Prasad ${ }^{1 \dagger}$, Evy De Leenheer ${ }^{1 \dagger}$, Nadine P Keefe ${ }^{1}$, Lorna A Ryan ${ }^{1}$, Jennifer Carlring ${ }^{1}$, \\ Andrew W Heath ${ }^{1,2^{*}}$
}

\begin{abstract}
Active vaccination can be effective as a post-exposure prophylaxis, but the rapidity of the immune response induced, relative to the incubation time of the pathogen, is critical. We show here that CD40mAb conjugated to antigen induces a more rapid specific antibody response than currently used immunological adjuvants, alum and monophosphoryl lipid $A^{\text {TM. }}$.
\end{abstract}

\section{Findings}

Post-exposure prophylaxis (PEP), or the induction of protection against an infectious disease after exposure to the pathogen, is either utilised or has been suggested as an appropriate course of action for a number of diseases, including rabies [1], anthrax [2], varicella [3,4], HIV and Hepatitis A [5]. PEP can be divided into three categories: The administration of antibiotics or antivirals, passive immunization using specific immunoglobulin, and active immunization (vaccination).

In some cases appropriate antimicrobial chemotherapy may not be available, or there may be a worry that the pathogen could be resistant to the agent, particularly in bioterrorism cases. Passive immunization using immunoglobulin may be a suitable alternative, if the pathogen is susceptible to antibody-mediated killing. However, active vaccination has the potential advantages of lower cost, less risk of adventitious pathogen transfer, and most importantly the induction of long-term protection. The use of active vaccination as PEP however depends upon the rapidity with which a protective immune response can be generated, in comparison with the incubation period of the pathogen post-exposure. The kinetics of the immune response are therefore a

\footnotetext{
* Correspondence: a.w.heath@shef.ac.uk

† Contributed equally

${ }^{1}$ Department of Infection and Immunity, University of Sheffield Medical
}

School, Beech Hill Rd, Sheffield S10 2RX, UK potential rate-limiting step for the efficacy of post-exposure vaccination.

Immune responses against vaccines are enhanced by immunological adjuvants. Aluminum salts are the only widely licensed immunological adjuvants [6], but the adjuvant monophosphoryl lipid $\mathrm{A}\left(\mathrm{MPL}^{\mathrm{Tm}}\right)$ is now licensed in some countries for use in the cervical cancer vaccine, Cervarix $^{\mathrm{mix}}$ [7] and may shortly be licensed for use in a wider range of vaccines. Aside from $\mathrm{MPL}^{\mathrm{m}}$, there is a large amount of research ongoing into other potential adjuvants, including host co-stimulatory molecules [8], TLR agonists [6,9], other particulate carriers $[10,11]$ and combinations of these approaches $[12,13]$.

Agonistic antibodies against the antigen presenting cell surface antigen CD40 are able to mimic the effect of binding of the ligand, CD154, both in vitro [14] and in vivo [15]. We have shown that agonistic CD40monoclonal antibody $(\mathrm{mAb})$ is an effective immunological adjuvant at low doses when chemically conjugated to antigen. It is able to enhance antibody $[16,17]$ as well as $\mathrm{T}$ helper responses [18]. CD40 antibody or ligand is also being investigated in cancer therapy and vaccination $[19,20]$. As we believe CD40mAb conjugate acts as an adjuvant at least in part via a direct effect on B cells [21], we were interested in assessing the rapidity of the antibody response induced by $\mathrm{CD} 40 \mathrm{mAb}$ in comparison with other adjuvants. We used the model antigen, ovalbumin, in order to compare the kinetics of the induced

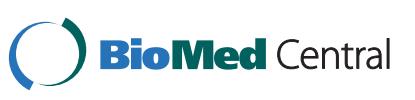

(c) 2010 Bhagawati-Prasad et al; licensee BioMed Central Ltd. This is an Open Access article distributed under the terms of the Creative Commons Attribution License (http://creativecommons.org/licenses/by/2.0), which permits unrestricted use, distribution, and reproduction in any medium, provided the original work is properly cited. 


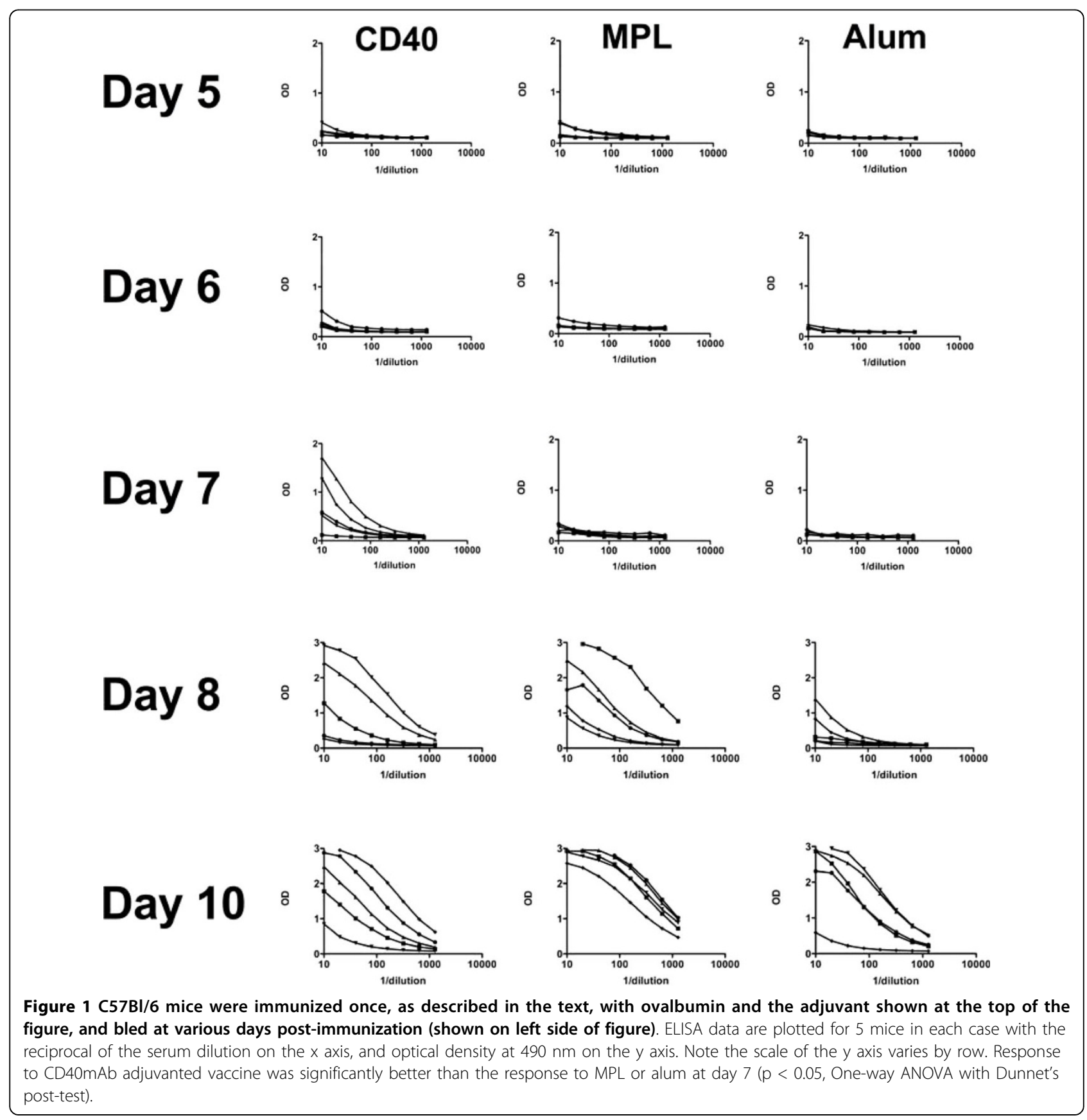

antibody response between $\mathrm{CD} 40$ conjugate, $\mathrm{MPL}^{\mathrm{m}}$ and the widely used alum adjuvant.

Female C57Bl/6 mice aged 6-8 weeks were obtained from Harlan UK Ltd and housed in accordance with strict Home Office guidelines. Ovalbumin (Sigma) was conjugated to the CD40mAb $10 \mathrm{C} 8$ [22] as previously described [16]. Four groups of 15 mice were immunised intraperitoneally with either $10 \mu \mathrm{g}$ of conjugate, $10 \mu \mathrm{g}$ of ovalbumin either alone, with $\mathrm{MPL}^{\mathrm{mi}}(10 \mu \mathrm{g}$, Sigma) or adsorbed onto Aluminium hydroxide $(200 \mu \mathrm{g}, 5)$. Five of the 15 mice were bled every 3 days in rotation, and anti-ovalbumin IgG endpoint titers determined by ELISA assay as previously described [16]

ELISA results are shown in Fig 1. CD40mAb conjugate induced an IgG response against OVA by day 7 post immunization, whereas no IgG response to OVA $+\mathrm{MPL}^{\mathrm{ma}}$ or OVA+alum was seen until day 8 , and in the case of alum this was weak. The results shown are representative of a total of three experiments. Total immunoglobulin responses (including IgM) tended to 
arise a day earlier, but showed the same difference in kinetics between CD40 and the other two adjuvants.

CD40mAb-OVA conjugate induces a more rapid IgG response in mice than either the established adjuvant, alum, or the newer adjuvant, MPL ${ }^{\mathrm{m}}$. How much faster the response to a CD40mAb vaccine versus an MPL adjuvanted vaccine would be in humans would need to be determined empirically. How important a more rapid response would be would depend upon the titers required to protect against a particular pathogen, as well as the window of opportunity available to prevent disease. We propose that $\mathrm{CD} 40 \mathrm{mAb}$ conjugates may have utility in post-exposure prophylaxis when a rapid antibody response is desirable.

\section{Abbreviations used}

MPL: monophosphoryl lipid A; TLR: Toll like receptor; ELISA: Enzyme linked immunosorbent assay; PEP: postexposure prophylaxis; mAb: monoclonal antibody.

\section{Author details}

'Department of Infection and Immunity, University of Sheffield Medical School, Beech Hill Rd, Sheffield S10 2RX, UK. ${ }^{2}$ Adjuvantix Ltd, c/o Fusion plc, Sheffield Bioincubator, Leavygreave Rd, Sheffield, UK.

\section{Authors' contributions}

$V B, E D, N K$ and $L R$ performed the experimental work. Experiments were designed by JC, ED and $\mathrm{AH}$. AH, ED and JC wrote the manuscript. All authors have read and approved the final manuscript.

\section{Competing interests}

$\mathrm{AH}$ is a Director of Adjuvantix Ltd and also holds some stock in Adjuvantix. Adjuvantix Ltd have an interest in CD40mAb based immunological adjuvants.

Received: 21 December 2009

Accepted: 4 February 2010 Published: 4 February 2010

\section{References}

1. Ertl HC: Novel vaccines to human rabies. PLoS Negl Trop Dis 2009, 3:e515.

2. Inglesby TV, O'Toole T, Henderson DA, Bartlett JG, Ascher MS, Eitzen E, Friedlander AM, Gerberding J, Hauer J, Hughes J, McDade J, Osterholm MT, Parker G, Perl TM, Russell PK, Tonat K: Anthrax as a biological weapon, 2002: updated recommendations for management. JAMA 2002 287:2236-2252.

3. Watson B, Seward J, Yang A, Witte P, Lutz J, Chan C, Orlin S, Levenson R: Postexposure effectiveness of varicella vaccine. Pediatrics 2000, 105:84-88.

4. Salzman MB, Garcia C: Postexposure varicella vaccination in siblings of children with active varicella. Pediatr Infect Dis J 1998, 17:256-257.

5. Kohl I, Nemecek V, Summerová M, Chlíbek R, Nad'ová K, Mináriková O: Long-term protective effect of post-exposure Havrix administration during viral hepatitis Type A outbreaks. Eur J Epidemiol 2006, 21:893-899.

6. Tagliabue A, Rappuoli R: Vaccine adjuvants: the dream becomes real. Hum Vaccin 2008, 4:347-349.

7. Paavonen J, Naud P, Salmeron J, Wheeler CM, Chow SN, Apter D,

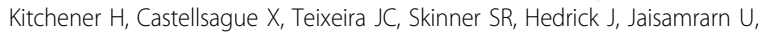
Limson G, Garland S, Szarewski A, Romanowski B, Aoki FY, Schwarz TF, Poppe WA, Bosch FX, Jenkins D, Hardt K, Zahaf T, Descamps D, Struyf F, Lehtinen M, Dubin G, Greenacre M: Efficacy of human papillomavirus (HPV)-16/18 AS04-adjuvanted vaccine against cervical infection and precancer caused by oncogenic HPV types (PATRICIA): final analysis of a double-blind, randomised study in young women. Lancet 2009, 374:301-314.
8. Barr TA, Carlring J, Heath AW: Co-stimulatory agonists as immunological adjuvants. Vaccine 2006, 24:3399-3407.

9. De Gregorio E, D'Oro U, Wack A: Immunology of TLR-independent vaccine adjuvants. Curr Opin Immunol 2009, 21:339-345.

10. Mesa C, de Leon J, Fernandez LE: Very small size proteoliposomes derived from Neisseria meningitidis: An effective adjuvant for generation of CTL responses to peptide and protein antigens. Vaccine 2006, 24:2692-2699.

11. Singh M, Chakrapani A, O'Hagan D: Nanoparticles and microparticles as vaccine-delivery systems. Expert Rev Vaccines 2007, 6:797-808.

12. Hatzifoti C, Bacon A, Marriott H, Laing P, Heath AW: Liposomal coentrapment of CD40mAb induces enhanced lgG responses against bacterial polysaccharide and protein. PLOS ONE 2008, 3:e2368.

13. Ahonen $\mathrm{CL}$, Doxsee $\mathrm{CL}$, McGurran $\mathrm{SM}$, Riter TR, Wade WF, Barth RJ, Vasilakos JP, Noelle RJ, Kedl RM: Combined TLR and CD40 triggering induces potent CD8+ T cell expansion with variable dependence on type I IFN. J Exp Med 2004, 199:775-784.

14. Heath AW, Chang R, Harada N, Santos-Argumedo L, Gordon J, Hannum C, Campbell $D$, Shanafelt AB, Clark EA, Torres $R$, et al: Antibodies to murine CD40 stimulate normal $B$ lymphocytes but inhibit proliferation of B lymphoma cells. Cell Immunol 1993, 152:468-480.

15. Dulforce P, Sutton DC, Heath AW: Enhancement of T cell-independent immune responses in vivo by CD40 antibodies. Nat Med 1998, 4:88-91.

16. Barr TA, McCormick AL, Carlring J, Heath AW: A potent adjuvant effect of CD40 antibody attached to antigen. Immunology 2003, 109:87-92.

17. Hatzifoti $C$, Heath AW: CD40-mediated enhancement of immune responses against three forms of influenza vaccine. Immunology 2007 122:98-106.

18. Carlring J, Barr TA, McCormick AL, Heath AW: CD40 antibody as an adjuvant induces enhanced T cell responses. Vaccine 2004, 22:3323-3328.

19. Tang Y, Akbulut H, Maynard J, Petersen L, Fang X, Zhang WW, Xia X, Koziol J, Linton PJ, Deisseroth A: Vector prime/protein boost vaccine that overcomes defects acquired during aging and cancer. J Immunol 2006, 177:5697-5707.

20. Vonderheide $\mathrm{RH}$ : Prospect of targeting the CD40 pathway for cancer therapy. Clin Cancer Res 2007, 13:1083-1088.

21. Barr TA, Carlring J, Heath AW: CD40 antibody as a potent immunological adjuvant: CD40 antibody provides the CD40 signal to B cells, but does not substitute for T cell help in responses to TD antigens. Vaccine 2005 23:3477-3482.

22. Barr TA, Heath AW: Functional activity of CD40 antibodies correlates to the position of binding relative to CD154. Immunology 2001, 102:39-43.

\section{doi:10.1186/1476-8518-8-1}

Cite this article as: Bhagawati-Prasad et al: CD40mAb adjuvant induces a rapid antibody response that may be beneficial in post-exposure prophylaxis. Journal of Immune Based Therapies and Vaccines 2010 8:1.

\section{Submit your next manuscript to BioMed Central and take full advantage of:}

- Convenient online submission

- Thorough peer review

- No space constraints or color figure charges

- Immediate publication on acceptance

- Inclusion in PubMed, CAS, Scopus and Google Scholar

- Research which is freely available for redistribution 